\title{
Sex work stigma and non-disclosure to health care providers: data from a large RDS study among FSW in Brazil
}

Inês Dourado 1* (D), Mark Drew Crosland Guimarães², Giseli Nogueira Damacena ${ }^{3}$, Laio Magno ${ }^{4}$, Paulo Roberto Borges de Souza Júnior ${ }^{3}$, Celia Landmann Szwarcwald ${ }^{3}$ and The Brazilian FSW Group

\begin{abstract}
Background: Stigma in health services may be detrimental to health seeking attitudes and practices. This study investigates non-disclosure of sex work to health care providers among female sex workers (FSW) in Brazil and its association with the utilization of health care services.

Methods: This study used cross-sectional respondent-driven sampling, carried out in 12 Brazilian cities to identify HIV risk behaviors among FSW. We first assessed statistical associations of sociodemographic, human right violations, health service access and utilization, and discrimination variables with non-disclosure of FSW status to health care providers as outcome. Secondly, we investigated the association of non-disclosure of FSW status with selected preventive health care outcomes: HIV testing, PAP smear exam, and post-exposure prophylaxis (PEP). Adjusted odds ratio with 95\% confidence intervals were calculated by multivariable logistic regressions.

Results: Among 4245 recruited FSW, a high percentage received free condoms (82\%) but only $24.4 \%$ were counseled on STI. Most FSW used non-specialized public healthcare routinely (62.6\%), but only $51.5 \%$ had a Pap smear exam in the last two years and less than 40\% were tested for HIV in the last 12 months. Among FSW who engaged in risky behavior (49.6\%), only 8.3\% used PEP. Regarding human rights violations, approximately 15\% were required to give part of their earnings to owners of workplace establishments, 38\% started sex work under 18 years old and $6 \%$ were required to periodically present their HIV test results. $21.3 \%$ reported having faced discrimination in health services, and $24.3 \%$ always disclosed their FSW status. Multivariable logistic models indicated significant associations of non-disclosure on the four healthcare outcomes, with lower odds of using preventive health services among women who did not disclose their sex work status, even after controlling for age, educational level, NGO affiliation, and type of health care routinely used.

Conclusions: Our results indicate that sex work stigmatization within health services may be one of the main barriers to STI control and HIV response among FSW. It is essential to combat stigmatization and discrimination against FSW in health services to guarantee the appropriate uptake of preventive services available in the public health system in Brazil.
\end{abstract}

Keywords: Female sex worker, human rights, stigma and discrimination, health care, RDS, Brazil

\footnotetext{
* Correspondence: ines.dourado@gmail.com

${ }^{1}$ Collective Health Institute, Federal University of Bahia, Av. Basílio da Gama,

s/n, Campus Universitário do Canela, Salvador, Bahia 40110-040, Brazil

Full list of author information is available at the end of the article
}

(c) The Author(s). 2019 Open Access This article is distributed under the terms of the Creative Commons Attribution 4.0 International License (http://creativecommons.org/licenses/by/4.0/), which permits unrestricted use, distribution, and reproduction in any medium, provided you give appropriate credit to the original author(s) and the source, provide a link to the Creative Commons license, and indicate if changes were made. The Creative Commons Public Domain Dedication waiver (http://creativecommons.org/publicdomain/zero/1.0/) applies to the data made available in this article, unless otherwise stated. 


\section{Background}

Since the beginning of the AIDS epidemic, female sex workers (FSW) have been recognized as a population with high vulnerability to HIV infection stemming from individual and interpersonal factors, including biologic (e.g. co-infection with other sexually transmitted infections (STI) [1]), behavioral attitudes and practices (e.g. higher pay for riskier sex acts such as unprotected sex and drug use), and structural factors (e.g. poor socioeconomic conditions, criminalization of sex work, residential instability and violence resulting from their work) [2-6]. Furthermore, stigma and discrimination are important barriers which potentially hamper access to and use of health services [7-9], especially due to fear of public exposure and consequent negative attitudes of service providers [10].

The human rights approach proposes that "the provision of health services should be ensured to all population groups on the basis of equality and freedom from discrimination, paying particular attention to vulnerable and marginalized groups" [11], which include FSW. In this regard, governments have an obligation to protect and fulfill the human rights of their vulnerable populations by promoting equitable access to health services and adopting appropriate legislative, administrative, budgetary, judicial, promotional and other measures towards the full realization of human rights [11].

Access to the publicly funded health system in Brazil was established as a universal right of citizens and a responsibility of the State under the federal constitution. The core principles of the Brazilian National Health System or Sistema Único de Saúde (SUS) - integrality (integrated prevention, treatment and care), equity, public accountability and funding - resulted from a long period of advocacy for governmental responsibility for health promotion [12, 13]. Despite these principles, many FSW suffer barriers to access health services because of stigma and discrimination related to the nature of their work.

In Brazil, it is estimated that $0.8 \%$ of the female population from 15 to 49 years of age have engaged in paid sex, accounting for approximately a half million women [14]. Although prostitution in Brazil is not considered a crime under Brazilian law [15], except if minors or sexual exploitation is involved, FSW constantly experience discrimination and condemnatory, moralist and punitive attitudes [16], along with other human rights violations such as violence and harassment, usually perpetrated by partners and the police. Furthermore, situations of discrimination against women at health care settings due to social class, lack of money, race and gender have been reported in population-based Brazilian studies [17, 18], with potential adverse health outcomes [19].
Stigma and discrimination have also been pointed out as fundamental causes of population health inequalities [20] and key barriers to health access for sex workers [21-24] mainly due to fear of discrimination in health services $[9,25,26]$. In order to avoid discriminatory experiences FSW may consciously adopt a form of social invisibility by not disclosing their sex work status to health care providers, thus potentially overcoming barriers to health care [27].

To our knowledge, previous studies have not investigated associations between anticipated stigma and access and uptake of health services in Brazil. The objective of this paper was to investigate non-disclosure of FSW status to health care providers and its association with access and uptake of preventive health care services (Pap smear, HIV testing, awareness and use of PEP).

\section{Methods}

\section{Study design}

This study reports results of a cross-sectional Biological and Behavioral Surveillance Survey (BBSS) among FSW conducted in 12 Brazilian cities, in 2016. Cities were defined, a priori, by the Department of STI/HIV/AIDS and Viral Hepatitis, Ministry of Health (DIAHV/MoH) representing the five regions of Brazil (São Paulo, Belo Horizonte and Rio de Janeiro Southeast Region; Curitiba and Porto Alegre - South Region; Brasília and Campo Grande - Central-West Region; Fortaleza, Recife and Salvador - Northeast Region; and, Belém and Manaus - North Region). Co-Investigators were responsible for conducting the study in each of the 12 cities and their names are listed under the Brazilian FSW Group.

Participants were recruited using respondent-driven sampling (RDS), and data was collected on HIV risk behavior practices, access to health services and situations of stigma and discrimination, among others. The research project was approved by the Oswaldo Cruz Foundation Ethics Committee (Protocol 1.338.989).

The sample size was set at $350 \mathrm{FSW}$ in each city. Women were eligible to participate in the study if they met the following inclusion criteria: age 18 years old or over; report working as a sex worker in one of the cities of the study; have had at least one sexual transaction in exchange for money in the past four months; present a valid RDS coupon to participate; and, signed written informed consent. RDS was chosen as the most appropriate method among available alternatives for reasons that included the hidden nature of FSW social networks [28-30].

Fieldwork was conducted in health services located in the 12 cities. As required by the RDS method, six to eight initial participants in each city - called seeds were chosen purposively, following formative qualitative research with focus groups with local FSW leaders, 
non-governmental organizations (NGO), potential participants, and researchers. Each seed received three coupons to distribute to other sex workers from her social network. The recruits of the seeds in the survey were considered the first wave of the study. After participating in the interview, each participant received three additional coupons to distribute to their peers and this process was repeated until the sample size was achieved in each site.

RDS requires a system of primary and secondary incentives. The primary incentive in this study was a gift (makeup products), payment for lunch and transportation in addition to a reimbursement for their time lost from work (approximately US\$15.00). The secondary incentive was a payment of US $\$ 10.00$ for each recruited person who participated in the study.

\section{Data Collection}

The questionnaire included modules on: sociodemographic characteristics and information related to professional activity, knowledge about HIV transmission, sexual behavior, previous HIV test - lifetime and in the last year, STI history, use of alcohol and illicit drugs, access to prevention activities and health services, discrimination and violence. The questionnaire was designed for tablet computers and could be self-administered according to the participant's desire and readiness. Tests for HIV, syphilis, and hepatitis $B$ and $C$ were conducted by standard rapid tests using peripheral venous blood collection, according to protocols recommended by the Brazilian Ministry of Health [31]. All tests occurred before the interview and all participants received pre- and post-test counseling. Participants who tested positive in any one of the rapid tests received additional post-test counseling, both to address the psychological impact and to encourage partner notification, and they were also referred to public health services for follow-up.

\section{Study Variables}

For this analysis, we defined four main groups of selected variables: socio-demographics, human rights violation indicators, access and uptake of health services indicators, disclosure of FSW status to health care providers and discrimination. Educational level was based on current Brazilian classification; race/skin color was categorized as white, black, brown or other (yellow, indigenous). FSW belonging to non-governmental organizations (NGO) was assessed as self-reported. Although prostitution is legal in Brazil for women aged 18 or over, the exploitation of sex workers is not. Thus, the following factors were taken as indicators of human rights violations against FSW as these are prohibited by labor laws in Brazil: a) requirement to give any percentage of their earnings to the owner of the establishment; b) requirement to give any percentage of their earnings to a pimp; c) sex work debut under 18 years old; d) compulsory submission of HIV test results to a supervisor in the workplace. Regarding access to uptake of health services, we considered the following indicators: a) use of a regular healthcare service (none, primary health care or specialized public health care services, and private services); b) had Pap smear exam in the last year, one to less than two years ago, three or more years ago, or never; c) HIV testing in the last year, one or more years ago, or never; d) awareness of post-exposure prophylaxis (PEP); e) PEP use if exposed to HIV risk over the past six months with PEP indication, i.e., condom breaking, bursting or sliding at least once; having been forced to have sex without a condom; and, client removed condom during sex without the FSW permission. Finally, as indicator of sex work disclosure and discrimination, we included: a) disclosure of FSW status to health care providers based on the following question: "When you go to a health service, do you disclose your sex work status to health care providers?" and it was categorized as always, sometimes, or never; and, b) perception of discrimination in the health services based on the question: "Have you ever felt discriminated against or treated worse than other people in the health services for being a FSW?" which was categorized as yes or no. Additionally, for those who answered never having had a Pap smear or HIV testing, we inquired whether this was due to shame of disclosing their FSW status, as proposed by UNAIDS [32].

\section{Data analysis}

Statistical methods appropriate for RDS design were used for data analysis, taking into account the dependence among observations resulting from the recruitment chains, and the unequal probabilities of selection resulting from the different sizes of networks of each participant. Seeds were excluded from this analysis considering that they were not recruited by their peers and did not contribute to the social network size used for weighting [33]. Each city composed a stratum, and each group of women recruited by the same FSW composed a cluster. The weighting was based on the inverse probability of selection proportional to the size of the network of each participant [33]. In this study, the question used to measure the network size of each participant and the resulting weighting was: "How many sex workers who work here in this city do you know personally?". Network sizes were limited to the range $3-150$, i.e., network sizes of one and two were recoded to three and higher values to 150 .

Overall descriptive analysis was conducted, and analyses of associations were divided into two parts. We initially assessed potential statistical associations of sociodemographics, human rights violations, access and 
uptake of health services with non-disclosure of FSW status to health care providers. Those who answered "never disclosing" were compared to those who always or sometimes disclosed their FSW status. Adjusted odds ratios (AOR) with 95\% confidence intervals were then estimated using multivariable logistic regression modeling of those variables statistically significant $(p<0.05)$ in the univariable assessment.

In the second part, we assessed the association of non-disclosure, now as potential predictor with two levels ("never disclosing" and always/sometimes disclosed their FSW status), on four indicators of preventive health care (1. Pap smear exam in the last two years, 2. HIV testing in the last year, 3. awareness of PEP, and 4. PEP use after exposure to risk). We chose these indicators as they measure access to important health care to prevent HIV and cervical cancer mortality among women. For each one of these four indicators, we calculated the AOR of non-disclosure of FSW status to health care providers after controlling for age, educational level, belonging to a FSW NGO, type of health service routinely used, and perception of discrimination.

\section{Results}

Among 4328 FSW recruited into the study, 4245 women 18 years and over were included in this analysis, after excluding the seeds. The average number of FSW recruited by each participant was 2.6. Approximately $50.0 \%$ were younger than 30 years old, $48.0 \%$ had not completed high school, $52.3 \%$ self-reported as brown (someone from a mixed race), and only $8.0 \%$ belonged to an NGO (Table 1). As to human rights violations, approximately $15.0 \%$ had to give part of their earnings to the establishment owner or to the pimp, and $38.0 \%$ started sex work under 18 years old. Compulsory submission of an HIV test results to a supervisor in the workplace was reported by $6.3 \%$.

As access to and uptake of health services, most FSW used primary health care routinely (62.6\%), 5.6\% used private health care, and only $2.5 \%$ used publicly funded specialized health care. A large proportion (29.0\%) did not have a regular source of health services. The proportion of FSW who had a Pap smear exam in the past two years was close to $50 \%$. HIV testing at least once in their lifetime was high (77.4\%), but less than $40 \%$ had been tested over the last 12 months. Awareness of PEP was reported by $31 \%$ and, among FSW who reported engaging in risky behavior over the past six months with PEP indication (49.6\%), only $8.3 \%$ used PEP (Table 1).

More than half of the women never disclosed their FSW status $(51.5 \%)$ to health care providers and $21 \%$ felt discriminated against or were treated worse than other people for being FSW. Furthermore, 14.7\% and

Table 1 Socio-demographics, social rights, human rights violations, and health care indicators among FSW. Brazil, 2016

\begin{tabular}{llll}
\hline Variables & $\mathrm{n}$ & Percentage (\%) & $95 \% \mathrm{Cl}$ \\
\hline $\begin{array}{l}\text { Socio-demographics } \\
\text { Age group }\end{array}$ & & & \\
$\quad 18-29$ & 2110 & 49.7 & $47.6-51.8$ \\
$30-39$ & 1118 & 26.3 & $24.6-28.1$ \\
$\quad 40-49$ & 650 & 15.3 & $13.9-16.8$ \\
50+ & 367 & 8.6 & $7.6-9.8$ \\
Educational level & & & \\
$\quad$ Incomplete elementary school & 626 & 14.9 & $13.5-16.4$ \\
$\quad$ Incomplete high school & 1386 & 32.9 & $31.1-34.8$ \\
Complete high school & 1096 & 26.0 & $24.3-27.8$ \\
Incomplete college or more & 1104 & 26.2 & $24.5-28.0$ \\
Belonging to FSW NGO & & & \\
$\quad$ Yes & 326 & 7.8 & $9.8-8.9$ \\
No & 3859 & 92.2 & $91.1-93.2$
\end{tabular}

Human Rights violations

Required to give a percentage of their earnings to owner of the establishment

$\begin{array}{llll}\text { Yes } & 524 & 12.5 & 11.1-13.9 \\ \text { No } & 3681 & 87.5 & 86.1-88.9\end{array}$

Required to give a percentage of their earnings to a pimp

Yes

No

Started sex work under 18 years old

$$
\text { Yes }
$$

No

The workplace required periodic HIV testing

Yes

No

Health service utilization

Regular source of care

Does not have one

Primary health care

Public specialized health care

Private health care

Had Pap smear exam in

Less than 1 year ago

1 to less 2 years ago

2 to less than 3 years ago

3 years or more ago

Never

\section{$175 \quad 4.2$}

$4026 \quad 95.8$

1628

\section{$27.2-30.9$ \\ 60.9-64.9 \\ 1.9-3.2 \\ 4.8-6.5}

$230 \quad 5.6$

29.7-33.3

18.5-21.6

9.6-12.3

17.0-20.1

$17.7-20.8$

\section{Had HIV testing in}


Table 1 Socio-demographics, social rights, human rights violations, and health care indicators among FSW. Brazil, 2016 (Continued)

\begin{tabular}{llll}
\hline Variables & $\mathrm{n}$ & Percentage (\%) & $95 \% \mathrm{Cl}$ \\
\hline $\begin{array}{l}\text { 1 year or more ago } \\
\text { Never }\end{array}$ & 1592 & 38.1 & $36.2-40.0$ \\
$\begin{array}{l}\text { Awareness of PEP } \\
\quad \text { Yes }\end{array}$ & 1299 & 31.1 & $21.0-24.3$ \\
$\quad$ No & 2880 & 68.9 & $29.3-33.3$ \\
Risk exposure in the past & & & $67.0-70.7$ \\
$\begin{array}{l}\text { months with PEP indication } \\
\text { b }\end{array}$ & & & \\
$\quad$ Yes & 2079 & 49.6 & $47.6-51.5$ \\
$\quad$ No & 2116 & 50.4 & $48.5-52.4$ \\
$\begin{array}{l}\text { PEP use among FSW exposed } \\
\text { to risk }\end{array}$ & & & \\
$\quad$ Yes & 172 & 8.3 & $6.8-10.0$ \\
$\quad$ No & 1907 & 91.7 & $90.0-93.2$ \\
\hline
\end{tabular}

${ }^{a}$ PEP: post exposure prophylaxis

${ }^{\mathrm{b}}$ Condom broke, burst, slid at least once or was forced to have sex without a condom or the condom was removed during sex without permission at least once over the past 6 months

$12.1 \%$ reported shame of revealing their FSW status as the reason for never having had a Pap smear exam or HIV testing, respectively (Table 2).

Results of the initial univariable and multivariable analyses of non-disclosure of FSW status to health care providers are seen in Tables 3 and 4 respectively. The multivariable analysis shows statistically significant associations of age (younger women) with non-disclosure of FSW status to health care providers. Educational level (lower education), and belonging to FSW NGO were associated with disclosure of FSW status to health care providers. In addition, the odds of non-disclosure were higher among FSW who did not have a regular source of health care $(\mathrm{OR}=2.36)$ or among those who used private

Table 2 Disclosure of FSW status and perception of discrimination in health services. Brazil, 2016

\begin{tabular}{|c|c|c|c|c|}
\hline Indicators & & $\mathrm{n}$ & $\begin{array}{l}\text { Percentage } \\
(\%)\end{array}$ & $95 \% \mathrm{Cl}$ \\
\hline \multirow{3}{*}{$\begin{array}{l}\text { Disclosure of FSW status } \\
\text { to a health care staff }\end{array}$} & Always & 1014 & 24.3 & $22.7-25.9$ \\
\hline & Not always & 1012 & 24.2 & $22.6-25.9$ \\
\hline & Never & 2153 & 51.5 & $49.6-53.5$ \\
\hline \multirow{2}{*}{$\begin{array}{l}\text { Perception of discrimination } \\
\text { or were treated worse in } \\
\text { health services for being } \\
\text { a FSW }\end{array}$} & Yes & 893 & 21.3 & 19.8-23.0 \\
\hline & No & 3294 & 78.7 & $77.0-80.2$ \\
\hline \multirow{2}{*}{$\begin{array}{l}\text { Had never had a Pap } \\
\text { smear because of shame } \\
\text { of disclosing FSW status }\end{array}$} & Yes & 100 & 14.7 & $11.4-18.7$ \\
\hline & No & 584 & 85.3 & $81.3-88.6$ \\
\hline \multirow{2}{*}{$\begin{array}{l}\text { Had never tested for HIV } \\
\text { because of shame of } \\
\text { disclosing FSW status }\end{array}$} & Yes & 112 & 12.1 & $9.4-15.4$ \\
\hline & No & 816 & 87.9 & $84.6-90.6$ \\
\hline
\end{tabular}

health care $(\mathrm{OR}=1.99)$, as compared to public specialized health care (Table 3).

Finally, the association of non-disclosure of FSW status to health care providers with preventive care indicators is presented in Table 4, after adjusting for age, educational level, belonging to FSW NGO, and regular source of health care. Non-disclosure of FSW status to health care providers was statistically associated $(p<$ 0.05 ) with all four indicators with lower odds of using preventive health care among women who did not disclose the FSW status to health care providers compared to FSW who always revealed their status. Similar results were found for awareness of PEP and PEP use when exposed to HIV risk.

\section{Discussion}

The Brazilian state is signatory to all international agreements that directly or indirectly guarantee women's human rights, as well as the elimination of all forms of discrimination and violence based on gender. Although prostitution is a non-criminalized occupation in Brazil, there are many violations of female sex workers' human rights. Currently, the requirement to pay back part of their earnings to third parties, as our results indicate, is considered exploitation of sex work and this is not legally permitted.

The comparison of our current analysis with those found in a previous study carried out by us in 2009 with a similar methodology [34] shows that engaging in paid sex is starting earlier. While in 2009 the proportion of girls who engaged in paid sex under the age of 18 years old (a sexual exploitation of minors) was 28\%, in 2016 this percentage rose to $39 \%$, with a worrisome $13 \%$ starting at age 14 years old or less.

Compulsory submission of test results to a supervisor in the workplace or pimps is an additional violation of FSW human rights, as compulsory assessment as well as dismissal from any employment due to HIV infection are forbidden by law [6]. Since there is no official job contract, in general FSW are merely removed from the workplace, without any social guarantee, such as unemployment insurance. It should be noted that $70 \%$ of the FSW interviewed in the present study favored sex work regulations and a possible formal contract providing legal job guarantees. But, only $2 \%$ reported having such a work contract.

The implementation of the Brazilian Health System represented an important change in the organization of health services in the country, especially with the strengthening of primary health care (PHC). The Family Health Program is the main approach to provide primary care services within Brazil's national health system in an effort to also reach underserved communities [35]. The results of this study confirm the use of PHC units as the main source of care among FSW, with only a small 
Table 3 Factors associated to non-disclosure of FSW status to health care staff

\begin{tabular}{|c|c|c|c|c|c|c|c|}
\hline \multirow[t]{2}{*}{ Variables } & & \multicolumn{6}{|c|}{ Non-disclosure of FSW status to health care staff } \\
\hline & & OR & $95 \% \mathrm{Cl}$ & $p$-value & Adjusted OR & $95 \% \mathrm{Cl}$ & $p$-value \\
\hline \multirow[t]{4}{*}{ Age } & $18-29$ & 1.56 & $1.22-2.00$ & $<0.001$ & 1.32 & $1.02-1.72$ & 0.034 \\
\hline & $30-39$ & 1.42 & $1.06-1.90$ & 0.018 & 1.23 & $0.91-1.66$ & 0.180 \\
\hline & $40-49$ & 1.17 & $0.91-1.50$ & 0.219 & 1.04 & $0.80-1.35$ & 0.749 \\
\hline & $50+$ & 1.00 & - & - & 1.00 & - & - \\
\hline \multirow[t]{4}{*}{ Educational level } & $\begin{array}{l}\text { Incomplete elementary } \\
\text { school }\end{array}$ & 0.57 & $0.43-0.76$ & $<0.001$ & 0.65 & $0.48-0.88$ & 0.005 \\
\hline & Incomplete high school & 0.69 & $0.54-0.87$ & 0.002 & 0.70 & $0.55-0.90$ & 0.006 \\
\hline & Complete high school & 0.99 & $0.77-1.28$ & 0.964 & 0.99 & $0.76-1.27$ & 0.912 \\
\hline & Incomplete college or more & 1.00 & - & - & 1.00 & - & - \\
\hline \multirow[t]{2}{*}{ Belonging to FSW-NGO } & Yes & 0.66 & $0.50-0.88$ & 0.005 & 0.72 & $0.53-0.98$ & 0.036 \\
\hline & No & 1.00 & - & - & 1.00 & - & - \\
\hline \multirow[t]{4}{*}{ Regular source of care } & Does not have one & 2.82 & $1.62-4.89$ & $<0.001$ & 2.36 & $1.31-4.24$ & 0.004 \\
\hline & Private care & 2.51 & $1.32-4.76$ & 0.005 & 1.99 & $1.02-3.91$ & 0.045 \\
\hline & Public specialized care & 1.00 & - & - & 1.00 & - & - \\
\hline & Public not specialized care & 1.47 & $0.87-2.50$ & 0.151 & 1.26 & $0.72-2.22$ & 0.414 \\
\hline
\end{tabular}

portion seeking specialized care services. Our results indicate that non-disclosure of FSW status to health care providers was associated with poor uptake of preventive exams, such as Pap smear exam in the last 2 years and HIV testing in the last 12 months, despite availability of testing and screening services free of charge in $\mathrm{PCH}$ units.

We speculate that more preventive health services are offered to women who are considered "at higher risk for IST" such as FSW [36]. Because of the nature of the study design we cannot be certain of the direction of this association, the interpretation could also be that once FSW reveal their status, perception of discrimination occurs. This result should be further explored in other studies. Nevertheless, health care guidelines should recommend that health authorities should ensure that health providers be trained to deal with the stigma and discrimination associated with sex work.

As previously pointed out, stigma within health services may be detrimental to health seeking behaviors and constitute one of the main barriers to the HIV response [25, 26, 37, 38]. Furthermore, in the national HIV/AIDS surveillance system, the occupation of each reported HIV case is classified according to the Brazilian Occupation Classification. However, in spite of sex work being part of the list of occupations, it is seldom stated as the occupation in the surveillance system, greatly restricting analysis of AIDS incidence and HIV prevalence in this population group and limiting monitoring of interventions focused on FSW.

Anticipated stigma hampers access to health care, but this phenomenon is a structural problem in Brazilian society, which does not recognize the rights of FSW. The government bodies must adopt appropriate legislative, administrative, judicial, promotional and other measures to protect sex workers' human rights. Their ability to organize is a strategy against HIV/AIDS based on organization of sex workers to conduct programs to achieve most effective HIV prevention outcomes and human rights. It is known to be effective for reductions in HIV and STI outcomes and increases in consistent condom use with clients [39-42]. However, there are

Table 4 Association of non-disclosure of FSW status to health care staff with preventive health care, PEP awareness and use after controlling for selected variables. Brazil, 2016

\begin{tabular}{llll}
\hline Outcomes & \multicolumn{3}{l}{ Non-disclosure of FSW status to health care staff } \\
\cline { 2 - 4 } & Adjusted OR & $95 \% \mathrm{Cl}$ & $\mathrm{p}$-value \\
\hline Pap smear exam <2y ago & 0.82 & $0.67-0.99$ & 0.040 \\
HIV testing $<1$ y ago & 0.80 & $0.67-0.97$ & 0.020 \\
Awareness of PEP & 0.72 & $0.59-0.88$ & 0.001 \\
PEP use among FSW exposed to risk & 0.39 & $0.26-0.60$ & $<0.001$ \\
\hline
\end{tabular}

${ }^{2}$ Adjusted for age, educational level, belonging to NGO, and regular source of care 
structural barriers to implement this strategy because of stigma, discrimination and violence, and especially because of less and less financial resources from government and donors [43].

Regarding the use of PEP, the proportion of FSW who used PEP was rather small, less than $10 \%$, although half had been exposed to an HIV risk that should have triggered the use of PEP. In view of our current results showing that both awareness of PEP as well as its use are associated with non-disclosure of FSW status to health care providers, and that pre-exposure prophylaxis (PrEP) has recently been introduced in Brazil, it is urgent to develop public health policies which enable disclosure of sex work status to health care providers. Improvements have been achieved in the distribution of free condoms, regardless of the amount requested or reasons for large quantities with no-questions-asked policy (70\% received free condoms in satisfactory amounts). At the same time, it is essential to combat stigmatization and discrimination against FSW from health care providers in order to guarantee the appropriate uptake of preventive methods and treatment already available in the Brazilian public health system. Programs that foster inclusion of marginalized groups such as adolescent girls who engage in paid sex are also urgently needed.

\section{Limitations}

This was a cross-sectional RDS study. Although our analysis took into consideration the complex design of the study, potential homophily, size and duration of the recruitment chains may still hamper representativeness of the target population of interest. Potential correlations among some of our variables, e.g. perception of discrimination and disclosure, are also of concern for our multivariable modeling, with unclear direction of the association. In addition, since we considered only a limited number of potential predictors, unknown confounding can still be present.

\section{Conclusions}

Despite universal access to health services in the Brazilian public health system, the results of this study show that sex work stigmatization and discrimination in health services may be major barriers to the maximal effectiveness of prevention and care actions for FSW in Brazil. Interventions targeting stigma and discrimination against FSW in health care services are urgently needed to increase access to health services.

For a sustained HIV response, efforts must focus on building awareness of FSW health care rights and on addressing barriers to health care access and utilization, such as reducing sex work-related stigma, aiming at transforming health services into safe environments where FSW can disclose their status without fear of facing discrimination.
Moreover, community empowerment-based HIV responses must enable sex workers to develop and implement public health actions themselves, and to encourage recognition of sex work as legitimate work in society. Among adolescent girls less than 18 years' old who engage in paid sex, clear strategies are needed to reach this priority group despite the illicitness and social invisibility of adolescent girls.

\section{Abbreviations \\ AIDS: Acquired Immune Deficiency Syndrome; DIAHV/MoH: Department of STI/AIDS and Viral Hepatitis, Ministry of Health; FSW: Female Sex Workers; HIV: Human Immunodeficiency Virus; NGO: Non-Governmental Organization; OR: Odds ratios; PEP: Post-exposure prophylaxis; PHC: primary health care; PrEP: Pre-exposure prophylaxis; RDS: Respondent Driven Sampling; STI: Sexually transmitted infections; SUS: Brazilian National Health System; UNAIDS: Joint United Nations Programme on HIV/AIDS}

\section{Acknowledgements}

The authors would like to express their gratitude to the participants of the study, to the local teams that carried out the fieldwork in the 12 cities, and all collaborating NGOs. We are also grateful for the support of STI/HIV/AIDS and Viral Hepatitis Department of the Brazilian Minister of Health.

The Brazilian FSW Group was composed of: Celia Landmann Szwarcwald, Paulo Roberto Borges de Souza Júnior, Orlando C. Ferreira Jr., Giseli Nogueira Damacena, Neide Gravato da Silva, Rita Bacuri, Helena Brigido, Hermelinda Maia Macena, Ana Maria de Brito, Inês Dourado, Mark Drew Crosland Guimarães, Wanessa da Silva de Almeida, Alexandre Grangeiro, Carla Gianna Luppi, Karin Regina Luhm, Isete Maria Stella, Adriana Varela Espinola, Tânia Varela, Francisca Sueli da Silva.

\section{Funding}

Funding for this study was provided by Brazilian Ministry of Health, through its Secretariat for Health Surveillance and its Department of Prevention, Surveillance and Control of Sexually Transmitted Infections, HIV/AIDS and Viral Hepatitis through a grant number: LN7901-BR.

Availability of data and materials

The datasets used and/or analyzed during the current study are available from the corresponding author on reasonable request.

\section{Authors' contributions}

All authors contributed to the concept of the paper and writing. ID and CL were responsible for writing the final version of the manuscript. $C L$ and $G D$ were responsible for data analysis. MDCG and LM interpreted the results, and revised the final version of the manuscript. PRBSJ were responsible for data management and helped with a draft version of the manuscript. All authors have read and approved the paper, have met the criteria for authorship as established by the International Committee of Medical Journal Editors, believe that the paper represents honest work, and are able to verify the validity of the results reported.

\section{Ethics approval and consent to participate}

The study was approved by the Ethics Committee of the Oswaldo Cruz Foundation and followed the National Health Council (CNS) guidelines, assuring the subjects' voluntariness, anonymity and possibility of withdrawal at any moment in the study, through the signing of a consent form.

Consent for publication

All data are in aggregated form and no individual nor personal identification of participants are possible.

Competing interests

The authors declare that they have no competing interests.

\section{Publisher's Note}

Springer Nature remains neutral with regard to jurisdictional claims in published maps and institutional affiliations. 


\section{Author details}

'Collective Health Institute, Federal University of Bahia, Av. Basílio da Gama, s/n, Campus Universitário do Canela, Salvador, Bahia 40110-040, Brazil. ${ }^{2}$ Federal University of Minas Gerais, Belo Horizonte, Minas Gerais, Brazil. ${ }^{3}$ Institute of Scientific Communication and Information on Public Health of Oswaldo Cruz Foundation, Rio de Janeiro, Brazil. ${ }^{4}$ Department of Life Sciences, Bahia State University, Campus 1, Salvador, Bahia, Brazil.

\section{Received: 31 August 2017 Accepted: 25 January 2019}

Published online: 05 March 2019

\section{References}

1. Shakarishvili A, Dubovskaya L, Zohrabyan L, St Lawrence J, Aral S, Dugasheva L, Okan S, Lewis J, Parker K, Ryan C. Sex work, drug use, HIV infection, and spread of sexually transmitted infections in Moscow, Russian Federation. Lancet. 2005;366(9479):57-60.

2. Li Y, Detels R, Lin P, Fu X, Deng Z, Liu Y, Tan Y, Li J, Wu Z. Prevalence of Human Immunodeficiency Virus and sexually transmitted infections and associated risk factors among female sex workers in Guangdong Province, China. J Acquir Immune Defic Syndr. 2010:53(Suppl 1):S48.

3. Damacena GN, Szwarcwald CL, PRBd SJ. HIV risk practices by female sex workers according to workplace. Rev Saude Publica. 2014;48(3):428-37.

4. Štulhofer A, Landripet I, Božić J, Božičević I. HIV risks and HIV prevention among female sex workers in two largest urban settings in Croatia, 2008-2014. AIDS Care. 2015;27(6):767-71.

5. Lima FS, Merchán-Hamann E, Urdaneta M, Damacena GN, Szwarcwald CL. Factors associated with violence against female sex workers in ten Brazilian cities. Cad Saude Publica. 2017;33(2):1-15.

6. Shannon K, Strathdee SA, Goldenberg SM, Duff P, Mwangi P, Rusakova M, Reza-Paul S, Lau J, Deering K, Pickles MR. Global epidemiology of HIV among female sex workers: influence of structural determinants. Lancet. 2015;385(9962):55-71.

7. King EJ, Maman S, Bowling JM, Moracco KE, Dudina V. The influence of stigma and discrimination on female sex workers' access to HIV services in St. Petersburg, Russia. AIDS Behav. 2013;17(8):2597-603.

8. Yang Y, Wang J, Lin F, Zhang T, Yu F, Zhao Y, Zhang T. Stigma against HIV/ AIDS among female sex workers and general migrant women in eastern China. BMC Womens Health. 2015;15(1):2.

9. Wang Y, Li B, Zheng J, Sengupta S, Emrick CB, Cohen MS, Henderson GE. Factors Related to Female Sex Workers' Willingness to Utilize VCT Service: A Qualitative Study in Jinan City, Northern China. AIDS Behav. 2009;13(5):866-72.

10. Ghimire L, Smith WCS, van Teijlingen ER. Utilisation of sexual health services by female sex workers in Nepal. BMC Health Serv Res. 2011;11:79.

11. Tarantola D. Global justice and Human Rights in practice. Global Justice: Theory Practice Rhetoric. 2007;1:11-26.

12. Elias PEM, Cohn A. Health reform in Brazil: lessons to consider. Am J Public Health. 2003;93(1):44-8.

13. Paim J, Travassos C, Almeida C, Bahia L, Macinko J. The Brazilian Health System: history, advances, and challenges. Lancet. 2011;377(9779):1778-97.

14. Saúde. BMd: Pesquisa de conhecimento, atitudes e práticas na população brasileira. In: Secretaria de Vigilância em Saúde. Departamento de DST AeHV. Brasília: Brasília: Ministério da Saúde; 2016.

15. Brazil. Brazilian Criminal Code. Availlable in: http://www.planalto.gov.br/ ccivil_03/decreto-lei/Del2848compilado.htm.

16. Chacham AS, Diniz SG, Maia MB, Galati AF, Mirim LA. Sexual and reproductive health needs of sex workers: two feminist projects in Brazil. Reprod Health Matters. 2007;15(29):108-18.

17. Gouveia GC, Souza WV, Luna CF, Souza-Júnior PRB, Szwarcwald CL. Health care users' satisfaction in Brazil, 2003. Cad Saude Publica. 2005;21:S109-18.

18. Boccolini CS, Boccolini PMM, Damacena GN, Ferreira APS, Szwarcwald CL. Factors associated with perceived discrimination in health services of Brazil: Results of the Brazilian National Health Survey, 2013. Cien Saude Colet. 2016:21(2):371-8.

19. Pascoe EA, Smart Richman L. Perceived discrimination and health: a meta-analytic review. Psychol Bull. 2009;135(4):531.

20. Hatzenbuehler ML, Phelan JC, Link BG. Stigma as a fundamental cause of population health inequalities. Am J Public Health. 2013;103(5):813-21.

21. Cohan D, Lutnick A, Davidson P, Cloniger C, Herlyn A, Breyer J, Cobaugh C, Wilson D, Klausner J. Sex worker health: San Francisco style. Sex Transm Infect. 2006;82(5):418-22.
22. Kurtz SP, Surratt HL, Kiley MC, Inciardi JA. Barriers to health and social services for street-based sex workers. J Health Care Poor Underserved. 2005;16(2):345-61.

23. Scambler G, Paoli F. Health work, female sex workers and HIV/AIDS: Global and local dimensions of stigma and deviance as barriers to effective interventions. Soc Sci Med. 2008;66(8):1848-62.

24. Lazarus L, Deering KN, Nabess R, Gibson K, Tyndall MW, Shannon K. Occupational stigma as a primary barrier to health care for street-based sex workers in Canada. Cult Health Sex. 2012;14(2):139-50.

25. Folch C, Lazar C, Ferrer L, Sanclemente C, Casabona J. Female sex workers and access to social and health services in Catalonia: Influence of region of origin and place of work. AIDS Care. 2013;25(8):1033-8.

26. Beattie TSH, Bhattacharjee P, Suresh M, Isac S, Ramesh BM, Moses S Personal, interpersonal and structural challenges to accessing HIV testing, treatment and care services among female sex workers, men who have sex with men and transgenders in Karnataka state, South India. J Epidemio Community Health. 2012;66(Suppl 2):ii42-8.

27. Ham J, Gerard A. Strategic in/visibility: Does agency make sex workers invisible? Criminol Crim Just. 2014;14(3):298-313.

28. Cowan FM, Mtetwa S, Davey C, Fearon E, Dirawo J, Wong-Gruenwald R, Ndikudze T, Chidiya S, Benedikt C, Busza J. Engagement with HIV prevention treatment and care among female sex workers in Zimbabwe: a respondent driven sampling survey. PLoS One. 2013:8(10):e77080.

29. Lafort Y, Greener R, Roy A, Greener L, Ombidi W, Lessitala F, HaghparastBidgoli $H$, Beksinska M, Gichangi P, Reza-Paul S. Where do female sex workers seek HIV and reproductive health care and what motivates these choices? A survey in 4 cities in India, Kenya, Mozambique and South Africa. PLoS One. 2016;11(8):e0160730.

30. Lafort Y, Greener R, Roy A, Greener L, Ombidi W, Lessitala F, Haghparast-Bidgoli H, Beksinska M, Gichangi P, Reza-Paul S. HIV prevention and care-seeking behaviour among female sex workers in four cities in India, Kenya, Mozambique and South Africa. Tropical Med Int Health. 2016;21(10):1293-303.

31. Brasil. Manual técnico para o diagnóstico da infecção pelo HIV - 2a edição. In: Secretaria de Vigilância em Saúde, editor. Departamento de Vigilância CdDST, HIV, aids e hepatites virais. Brasília: Ministério da Saúde; 2015. p. 85

32. UNAIDS: Global AIDS Monitoring 2017. Indicators for monitoring the 2016 Unitec Natins Political Decalration on HIV and AIDS.; 2017.

33. Salganik MJ, Heckathorn DD. Sampling and estimation in hidden populations using respondent-driven sampling. Sociol Methodol. 2004;34(1):193-240.

34. Damacena GN, Szwarcwald CL, de Souza Júnior PRB, Dourado I. Risk Factors Associated With HIV Prevalence Among Female Sex Workers in 10 Brazilian Cities. J Acquir Immune Defic Syndr. 2011;57(Supplement 3):S144-52.

35. Escorel S, Giovanella L. Mendonça MHMd, Senna MdCM: The Family Health Program and the construction of a new model for primary care in Brazil. Rev Panam Salud Publica. 2007:21(2-3):164-76.

36. Pescosolido BA, Martin JK. The Stigma Complex. Annu Rev Sociol. 2015;41(1):87-116

37. Nyblade L, Reddy A, Mbote D, Kraemer J, Stockton M, Kemunto C, Krotki K, Morla J, Njuguna S, Dutta A, et al. The relationship between health worker stigma and uptake of HIV counseling and testing and utilization of non-HIV health services: the experience of male and female sex workers in Kenya. AIDS Care. 2017:29(11):1-9.

38. Chakrapani V, Newman PA, Shunmugam M, Kurian AK, Dubrow R. Barriers to Free Antiretroviral Treatment Access for Female Sex Workers in Chennai, India. AIDS Patient Care STDs. 2009;23(11):973-80.

39. Kerrigan DL, Fonner VA, Stromdahl S, Kennedy CE. Community empowerment among female sex workers is an effective HIV prevention intervention: a systematic review of the peer-reviewed evidence from low-and middle-income countries. AIDS Behav. 2013;17(6):1926-40.

40. Wirtz AL, Pretorius C, Beyrer C, Baral S, Decker MR, Sherman SG, Sweat M, Poteat T, Butler J, Oelrichs R. Epidemic impacts of a community empowerment intervention for HIV prevention among female sex workers in generalized and concentrated epidemics. PLoS One. 2014:9(2):e88047.

41. Kerrigan D, Wirtz A, Baral S, Decker M, Murray L, Poteat T. The Global HIV Epidemics among Sex Workers. Washington, DC: World Bank; 2013.

42. Moore L, Chersich MF, Steen R, Reza-Paul S, Dhana A, Vuylsteke B, Lafort Y, Scorgie F. Community empowerment and involvement of female sex workers in targeted sexual and reproductive health interventions in Africa: a systematic review. Glob Health. 2014;10(1):47.

43. Kerrigan D, Kennedy CE, Morgan-Thomas R, Reza-Paul S, Mwangi P, Win KT, McFall A, Fonner VA, Butler J. A community empowerment approach to the HIV response among sex workers: effectiveness, challenges, and considerations for implementation and scale-up. Lancet. 2015;385(9963):172-85. 